\title{
The feasibility of robotic-assisted concomitant procedures during mitral valve operations
}

\author{
Mitral kapak ameliyatlarında robotik yardımlı ek işlemlerin uygulanabilirliği
}

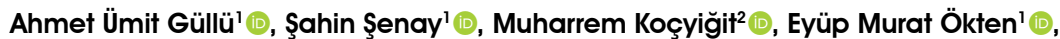 \\ Mert Dumantepe' ${ }^{1}$, Hasan Karabulut' ${ }^{1}$, Cem Alhan' ${ }^{(0)}$
}

\author{
'Department of Cardiovascular Surgery, Acıbadem Mehmet Ali Aydınlar University, Istanbul, Turkey \\ ${ }^{2}$ Department of Anesthesiology and Reanimation, Acıbadem Mehmet Ali Aydınlar University, Istanbul, Turkey
}

\begin{abstract}
Background: In this study, we present our clinical experience and midterm results with the robotic-assisted concomitant procedures during mitral valve operations.

Methods: Between March 2010 and February 2018, a total of 34 patients ( 8 males, 26 females; mean age 58.3 years; range, 34 to 78 years) who underwent robotic-assisted concomitant procedures during mitral valve surgery were retrospectively analyzed. Demographic characteristics of the patients, comorbidities, medical, and surgical histories, operative and laboratory results, electrocardiographic findings, postoperative intensive care unit and ward outcomes, and cardiac follow-up data were recorded. Atrial fibrillation-related medication use, stroke, or other thromboembolic events, and electrocardiographic reports in patients who underwent cryoablation were reviewed at three and 12 months after the operation.
\end{abstract}

Results: A total of 76 robotic-assisted concomitant procedures were performed during mitral valve repair $(n=11)$ or replacement $(n=23)$ in 34 patients. These procedures were cryoablation $(n=29)$, tricuspid valve repair $(n=6)$, tricuspid valve replacement $(n=2)$, left atrial appendage ligation $(n=32)$, atrial septal defect and patent foramen ovale closure $(n=5)$, and left atrial thrombectomy $(n=2)$. The mean preoperative EuroSCORE values were 5.1 \pm 2.5 . The mean duration of cardiopulmonary bypass and cross-clamp was $156 \pm 69.4 \mathrm{~min}$ and $101 \pm 42$ min, respectively. Normal sinus rhythm was restored in $85 \%$ of the patients (24/28) after cryoablation and two patients (5.8\%) had permanent pacemaker within a year during follow-up. There was one (2.9\%) mortality in the early postoperative period due to hemorrhage related to the posterior left ventricular wall rupture. No blood product was used in $82.4 \%$ of the patients. One patient had a transient cerebral event and symptoms regressed completely within two months.

Conclusion: Technological improvements and growing experience can decrease the suspects related to prolonged operational duration during robotic-assisted cardiac surgery. Concomitant procedures in addition to mitral valve operations can be performed with low complication rates in centers with experience of robotic surgery.

Keywords: Minimal invasive surgery, mitral valve surgery, robotic surgery.

\section{$\ddot{o Z Z}$}

Amaç: Bu çalışmada, mitral kapak ameliyatlarında robotik yardımlı ek işlemlere ilişkin klinik deneyimlerimiz ve orta dönem sonuçlarımız sunuldu.

Çalışma planı: Mart 2010 - Şubat 2018 tarihleri arasında mitral kapak ameliyatı sırasında robotik yardımlı ek işlem uygulanan toplam 34 hasta (8 erkek, 26 kadın; ort. yaş 58.3 yıl; dağılım, 34-78 yil) retrospektif olarak incelendi. Hastaların demografik özellikleri, eşlik eden hastalıkları, tıbbi ve cerrahi öyküleri, ameliyat ve laboratuvar sonuçları, elektrokardiyografik bulguları, ameliyat sonrası yoğun bakım ünitesi ve servis sonuçları ve kardiyak takip verileri kaydedildi. Kriyoablasyon yapilan hastalarda atriyal fibrilasyon ile ilişkili ilaç kullanımı, inme ve diğer tromboembolik olaylar ve elektrokardiyografik sonuçlar ameliyat sonrası üç ve 12 . aylarda değerlendirildi.

Bulgular: Mitral kapak tamiri $(n=11)$ veya replasmanı $(n=23)$ sırasında 34 hastaya toplam 76 robotik yardımlı ek işlem uygulandı. $\mathrm{Bu}$ işlemler kriyoablasyon $(\mathrm{n}=29)$, triküspid kapak tamiri $(\mathrm{n}=6)$, triküspit kapak replasmanı $(\mathrm{n}=2)$, sol atriyal apendiks ligasyonu $(n=32)$, atriyal septal defekt ve patent foramen ovale kapatılması $(n=5)$ ve sol atriyal trombektomi $(n=2)$ idi. Ameliyat öncesi ortalama EuroSCORE değerleri 5.1 \pm 2.5 idi. Ortalama kardiyopulmoner baypas ve kros klemp süreleri sırasiyla $156 \pm 69.4$ ve $101 \pm 42 \mathrm{dk}$. idi. Bir yıllık takip süresince kriyoablasyondan sonra hastaların \%85'inde $(24 / 28)$ normal sinüs ritmine ulaşıldı ve iki hastaya (\%5.8) kalıcı pacemaker takıldı. Ameliyat sonrası erken dönemde arka sol ventrikül duvar rüptürüne bağlı kanama nedeniyle bir hastada (\%2.9) mortalite izlendi. Hastaların \%82.4'ünde kan ürünü kullanılmadı. Bir hastada geçici serebral olay yaşandı ve semptomlar iki ay içinde tamamen geriledi.

Sonuç: Teknolojik ilerlemeler ve artan deneyim robotik yardımlı kalp cerrahisi sırasında ameliyat süresinin uzamasına ilişkin endişeleri azaltmaktadır. Robotik cerrahi deneyimi olan merkezlerde mitral kapak ameliyatlarına eşlik eden işlemler düşük komplikasyon oranları ile yapılabilir.

Anahtar sözcïkler: Minimal invaziv cerrahi, mitral kapak cerrahisi, robotik cerrahi.

Received: December 26, 2018 Accepted: March 04, 2019 Published online: October 23, 2019

Correspondence: Ahmet Ümit Güllü, MD. Acıbadem Mehmet Ali Aydınlar Üniversitesi, Kalp ve Damar Cerrahisi Anabilim Dalı, 34752 Ataşehir, Istanbul, Turkey. Tel: +90 216-5452959 e-mail: aumitgullu@yahoo.com operations. Turk Gogus Kalp Dama 2019;27(4):478-483 
The main advantages of robotic-assisted cardiac surgery include less pain, shortened hospital stay, early return to daily life, less infection, and almost no transfusion requirements. ${ }^{[1-3]}$ In addition, mortality and morbidity rates are similar to traditional incisions. ${ }^{[4]}$ Robotic surgery is technically feasible for the intervention of concomitant pathologies such as tricuspid valve insufficiency, atrial fibrillation (AF), and atrial septal defects (ASDs) during mitral valve operations. However, many surgical teams are not enthusiastic for concomitant procedures during robotic mitral valve operations related to concerns of the potential for prolonged duration of cross-clamp (CC) and cardiopulmonary bypass (CPB) ${ }^{[1]}$ With the advances of surgical experience and technological support, this concern has been gradually diminished.

In the present study, we present our clinical experience and mid-term results with robotic-assisted concomitant procedures during mitral valve operations.

\section{PATIENTS AND METHODS}

Between March 2010 and February 2018, a total of 238 patients underwent robotic-assisted cardiac procedures in Acıbadem Mehmet Ali Aydınlar University. A total of 34 patients ( 8 males, 26 females; mean age 58.3 years; range, 34 to 78 years) who underwent robotic-assisted concomitant procedures using the da Vinci $^{\circledast} \mathrm{Si}$, Xi HD surgical systems (Intuitive Surgical, Inc., Sunnyvale, CA, USA) during mitral valve surgery were retrospectively analyzed. Data including demographic characteristics of the patients, comorbidities, medical, and surgical histories, operative and laboratory findings, and postoperative outcomes were retrieved from the institutional database. The rhythm examination with a 12-lead electrocardiography (ECG) and 24-h Holter, and recordings of AF-related medication, stroke, or other thromboembolic events in patients who underwent cryoablation were evaluated by the cardiologist at three and 12 months following the operation. The robotic-assisted surgery and conventional approach were described with details to the all patients and surgical technique was selected according to patient request. Patients with prior thoracotomy causing dense right pleural adhesions and those with symptomatic obstructive coronary artery disease were excluded. Patients with asymptomatic obstructive coronary disease were considered first for robotic-assisted surgery and, then, percutaneous coronary revascularization was planned. A written informed consent was obtained from each patient. The study protocol was approved by the Cardiovascular Surgery Ethics Committee of
Acıbadem Mehmet Ali Aydınlar University. The study was conducted in accordance with the principles of the Declaration of Helsinki.

The severity of the mitral or tricuspid valve pathology and existence of other abnormalities were evaluated using transthoracic echocardiography. Coronary arteries were evaluated with conventional coronary angiography or computed tomography angiography. On the operating table, transesophageal echocardiography (TEE) was performed to evaluate the structure of valvular and subvalvular mitral apparatus and the options for valve repair. It also showed mitral and tricuspid valve annular size, evaluate the interatrial septum, the existence of calcification at ascending aorta and the other pathologies. In addition, TEE guided us not only prior the operation, but also during all part of the operation such as arterial cannulation and placing the venous cannulas to the jugular vein and vena cava inferior. The cannulation sides were examined via Doppler ultrasonography (USG), the existence of calcification at the femoral artery and the size of cannulas were determined. All interventions were evaluated via TEE following the removal of CC and reintervention was performed, if necessary.

\section{Surgical technique}

Our technique for robotic surgery has been already described in detail elsewhere. ${ }^{[5,6]}$ Briefly, following TEE examination, double-lumen endotracheal tube was inserted. Venous cannulation was achieved by internal jugular and femoral veins (Medtronic Bio-Medicus, Eden Prairie, MN, USA) and arterial cannulation (Medtronic Bio-Medicus, Eden Prairie, MN, USA) was performed via the femoral artery under the TEE guidance. A $3-\mathrm{cm}$ incision was made between the anterior axillary and midclavicular line at the fourth intercostal space and a small soft tissue retractor (Applied Medical, Rancho Santa Margarita, CA, USA) was placed. The right arm port was placed through the first or second intercostal spaces inferior to the soft tissue retractor, and the left arm port was placed one intercostal space superiorly (Figure 1). The robotic arms were docked. Following CPB institution, the heart was arrested with the Chitwood aortic clamp which was inserted through the chest wall in the direction of the transverse sinus and using of cold crystalloid cardioplegia (Custodiol, Essential Pharmaceuticals LLC, NC, USA) delivered into the aortic root via a temporary transthoracic cannula through the working port. The inferior and superior vena cavas were occluded with bulldog clamps. ${ }^{[6]}$ The inter-atrial groove was dissected, left atriotomy was performed and the atrial retractor was placed into the left atrium (LA). 


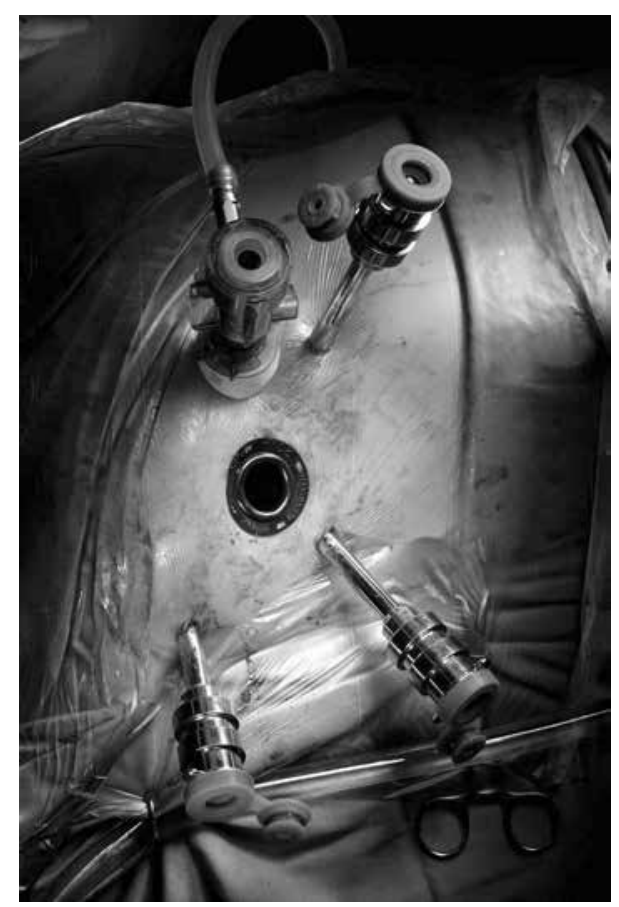

Figure 1. An intraoperative view of set-up for robotic-assisted mitral valve procedure.

The LA appendage was ligated in all patients with AF using a double-layered running Prolene 3.0 suture from the inside of the LA. In patients with AF, the cryoablation probe was delivered through the working port (Cardioblate, CryoFlex Medtronic Inc., MN, USA) which can be fit to the shape of the atrial wall, creating cryolesions of 1 to $10 \mathrm{~cm}$ in length. Principally, atrial cryolesions in this series were performed for $90 \mathrm{sec}$ reaching local temperatures of $-130^{\circ} \mathrm{C}$ and started with an ablation line extending from the atriotomy to the mitral valve annulus in the region P2/P3. The left and right pulmonary veins were isolated, an inferior and superior ablation line was placed to complete the box lesion for isolation of the posterior atrial wall, and an additional lesion was placed to connect the box to the closure line of the LA appendage. The LA was closed following the completion of mitral valve repair or replacement. In case of right atrial (RA) pathology, right atriotomy was created and the atrial retractor was placed into the RA. Additional cryoablation was performed in patients with atrial flutter or atrial fibrillation with an enlarged right RA. The RA lesion set consisted of an intercaval lesion extending from the superior vena cava to the inferior vena cava; from this lesion to tricuspid valve annulus, and finally from the first lesion to RA appendage. In patients with tricuspid valve insufficiency, valve was examined, annulus was sized for prosthesis, and pledgeted sutures were implanted. Once all the sutures were completed, they were passed through the annulus of the valve or ring prosthesis outside the thoracic cavity. The valve or ring was removed from its holder and deployed through the soft tissue retractor. The pledgeted sutures of the valve or ring were secured with an automatic mechanical knot fastening system (Cor-Knot, LSI Solution, Victor, NY, USA). The atriotomy was closed using a premade loop suture. Both bulldog clamps were released. After deairing, the aortic CC was released. Subsequently, TEE examination was performed to check any abnormal situation or air trap. The patient was, then, weaned from CPB, cannulas were removed, and protamine was administered.

Clinical, procedural, and postoperative data were prospectively recorded into the institutional database and retrieved for this retrospective review. Mortality was defined as death occurring at any time during the hospital stay and anywhere during a year after the operation.

\section{Statistical analysis}

Statistical analysis was performed using the Predictive Analytics SoftWare (PASW) version 18.0 statistical package (SPSS Inc., Chicago, IL, USA). Descriptive data were expressed in mean \pm standard deviation (SD), median (min-max), or number and frequency. A $p$ value of $<0.05$ was considered statistically significant.

\section{RESULTS}

A total of 76 robotic-assisted concomitant procedures were performed during mitral valve repair $(n=11)$ or replacement $(n=23)$ in 34 patients. These procedures were cryoablation $(n=29)$, tricuspid valve repair $(n=6)$, tricuspid valve replacement $(n=2)$, LA appendage ligation $(n=32)$, ASD and patent foramen ovale (PFO) closure $(\mathrm{n}=5)$, and LA thrombectomy $(n=2)$. Detailed procedure types in each patient and 30-day postoperative outcomes are presented in Tables 1 and 2, respectively.

The mean preoperative EuroSCORE values were 5.1 \pm 2.5 . The mean duration of $\mathrm{CPB}$ and $\mathrm{CC}$ was $156 \pm 69.4 \mathrm{~min}$ and $101 \pm 42 \mathrm{~min}$, respectively. Normal sinus rhythm was restored in $85 \%$ of the patients (24/28) after cryoablation and two patients (5.8\%) had permanent pacemaker within a year during follow-up.

There was one (2.9\%) mortality in the early postoperative period due to hemorrhage related to the posterior left ventricular wall rupture. No blood product was used in $82.4 \%$ of the patients. None of the patients developed renal failure requiring dialysis 
Table 1. Baseline demographic characteristics and postoperative outcomes $(n=34)$

$\mathrm{n} \quad \% \quad$ Mean \pm SD

\begin{tabular}{|c|c|c|c|}
\hline \multicolumn{3}{|c|}{ Preoperative characteristics } & \multirow[b]{2}{*}{$58.3 \pm 12$} \\
\hline Age (year) & & & \\
\hline \multicolumn{4}{|l|}{ Gender } \\
\hline Male & 8 & & \\
\hline Female & 26 & & \\
\hline Creatinine & & & $0.8 \pm 0.2$ \\
\hline Ejection fraction (\%) & & & $57.5 \pm 8.2$ \\
\hline EuroSCORE & & & $5.1 \pm 2.5$ \\
\hline \multicolumn{4}{|l|}{ Perioperative outcomes } \\
\hline CPB duration (min) & & & $156 \pm 69.4$ \\
\hline CC time (min) & & & $101 \pm 42$ \\
\hline Intubation duration (hour) & & & $11.1 \pm 24.3$ \\
\hline Blood products usage & & 17.6 & \\
\hline Pacemaker implantation & 2 & 5.8 & \\
\hline Hemorrhage $(\mathrm{mL})$ & & & $336.5 \pm 225.8$ \\
\hline \multicolumn{4}{|l|}{ Stroke } \\
\hline Permanent & 0 & 0 & \\
\hline Transient & 1 & 2.9 & \\
\hline Renal failure & 0 & 0 & \\
\hline ICU stay (hour) & & & $25.6 \pm 24.0$ \\
\hline Mortality & 1 & 2.9 & \\
\hline
\end{tabular}

SD: Standard deviation; CPB: Cardiopulmonary bypass; CC: Cross-clamp; ICU: Intensive care unit. or permanent stroke. One patient had a transient cerebral event and symptoms totally resolved within two months following the procedure.

\section{DISCUSSION}

Our current cohort including 34 patients with the additional pathologies beside mitral valve treated with the assistance of robotic systems showed acceptable postoperative results in the course of our robotic surgery program throughout an eight-year study period. Although the operative times of robotic operations were relatively longer than conventional procedures, it did not affect the outcomes. Also, CPB and aortic $\mathrm{CC}$ time can be reduced to acceptable levels with increasing experience. ${ }^{[2-4]}$ To prevent longer duration of operation, some modifications: using single shot crystalloid cardioplegia rather than delivering blood cardioplegia in every $20 \mathrm{~min}$, clamping both vena cavas with bulldog clamps using automatic mechanical knot fastening system and premade loop suture techniques can all decrease $\mathrm{CPB}$ and CC time nearly to conventional surgery during our program.

Robotic technology demonstrates obvious advantages over traditional video-assisted thoracoscopic surgery. Its three-dimensional (3D) high definition capabilities and articulating wrists allow a greater freedom of movement in an enclosed space compared

Table 2. Types of concomitant procedures during robotic-assisted surgery $(n=34)$

\begin{tabular}{lc}
\hline & $\mathrm{n}$ \\
\hline Mitral valve repair + LA cryoablation + LAL & 5 \\
Mitral valve repair + LAL+ ASD closure & 1 \\
Mitral valve replacement + TV repair + biatrial cryoablation + LAL & 1 \\
Mitral valve replacement + LA cryoablation + LAL & 14 \\
Mitral valve replacement + TV repair + LA cryoablation + LAL & 3 \\
Mitral valve replacement + TV replacement + biatrial cryoablation + LAL & 1 \\
Mitral valve replacement + biatrial cryoablation + LAL + PFO closure & 1 \\
Mitral valve replacement + LA cryoablation + LAL+ LA thrombectomy & 1 \\
Mitral valve repair + TV repair + biatrial cryoablation + LAL & 1 \\
Mitral valve repair + LA cryoablation + LAL + PFO closure & 1 \\
Mitral valve repair + PFO closure & 1 \\
Mitral valve repair + TV repair + LA cryoablation + LAL & 1 \\
Mitral valve replacement + LA thrombectomy + LAL & 1 \\
Mitral valve replacement + LAL + PFO closure & 1 \\
Mitral valve paravalvular leak repair + TV replacement & 1 \\
\hline LA: Left atrial; LAL: Left atrial appendage ligation; ASD: Atrial septal defects; TV: Tricuspid valve; PFO: Patent \\
foramen ovale.
\end{tabular}


with traditional long-shafted instruments. ${ }^{[7]}$ Beside the other advantages of robotic-assisted surgery, the da Vinci ${ }^{\circledR}$ robotic technology provides long and thinner shafted instruments with articulating instruments to move with six degrees of freedom, rather than four degrees and eliminates the surgeon's tremor, if present. Moreover, magnified 3D images and dynamic atrial retractor provide excellent exposure to the mitral valve and subannular anatomy allows one to address the entire spectrum of pathological complexity and intervention at more proximity to the surgical field. All these advantages of robotic assistance compared to the conventional or thoracoscopic approach may enhance the probability of valvular repair. The other fact is that it is more difficult to perform the correction of the pathology with straight-shafted and long instruments during direct vision or endoscopic technique versus dexterous robotic arms. In a recent study, Loulmet et al. ${ }^{[2]}$ showed excellent results in 500 patients undergoing mitral valve procedure with robotic assistance. The results reflect an overall repair rate of $99.4 \%$ (100\% in degenerative disease without mitral annular calcification) with $0.6 \%$ early mortality and a $1.2 \%$ stroke rate. With both conventional median sternotomy or endoscopic technique, this success rate is likely not as applicable as robotics for many patients with complex mitral valve disease.

In the literature, there is a very limited number of studies showing the results of cryoablation procedure with robotic assistance. ${ }^{[8]}$ During one-year follow up, $85 \%$ of our patients with preoperative AF had sinus rhythm following cryoablation. The cryoprobe can be molded to conform geometrically to an individual atrial anatomy with the use of robotic forceps. The combination of dynamic LA retraction, improved dexterity using Endowrist ${ }^{\mathrm{TM}}$ technology (Intuitive Surgical Inc., Sunnyvale, CA, USA), and 3D vision allows surgeon for precise placement of the cryoprobe and avoidance of skips caused by folds in the floor of the LA (Figure 2).

All patients with moderate-to-severe tricuspid valve insufficiency during concomitant robotic mitral valve surgery underwent tricuspid valve repair or replacement in our study. The need for bicaval occlusion necessitates some changes regarding the strategy for cannulation; as such, unlike robotic mitral operations, the venous cannulas at the superior and inferior vena cavas should not reach the RA, but be away, leaving at least 1 to $2 \mathrm{~cm}$ of open space for endoscopic bulldog clamps.

Furthermore, robotic ASD closure is technically feasible and safe with a high success and a low complication rate. ${ }^{[9-12]}$ In our study, ASD or PFO was observed in addition to mitral valve pathology in four patients and the defects were closed with primary suture or pericardial patch. All intraoperative measurements including the size of the pericardial patch should be done with a ruler. The magnified robotic images may mislead one to improper sizing. Also, the anatomical position of the interatrial septum may necessitate the use of a $0^{\circ}$ endocamera, unlike robotic mitral operations.

However, there are some disadvantages of this technology such as limited availability of robotic systems and high costs. There is also a necessity of a learning curve and the lack of tactile feedback. With the growing experience, robotic surgeons have become familiar with relying on visualization to judge the amount of force being applied to tissues. Future robotic systems would likely incorporate some special sensors to the robotic arms allowing for haptic feedback and precise control of force. ${ }^{[12]}$

In our program, we do not have any systematic exclusion criteria for robotic mitral valve procedures, although intensive pleural adhesions may complicate the procedure during pleural dissection. Symptomatic coronary artery disease, aortic valve insufficiency, and pectus excavatum may be also other contraindications for this procedure.

The present study report only one-year follow-up period which is one of the main limitations of our study; however, previous studies of long-term results of robotic-assisted mitral valve surgery have demonstrated that survival and durability are similar to those obtained with non-robotic approaches. ${ }^{[2-4]}$ These excellent results in a large series, similar to those of others, emphasize that the results are reproducible. ${ }^{[7]}$ In addition, retrospective nature of our study and the small

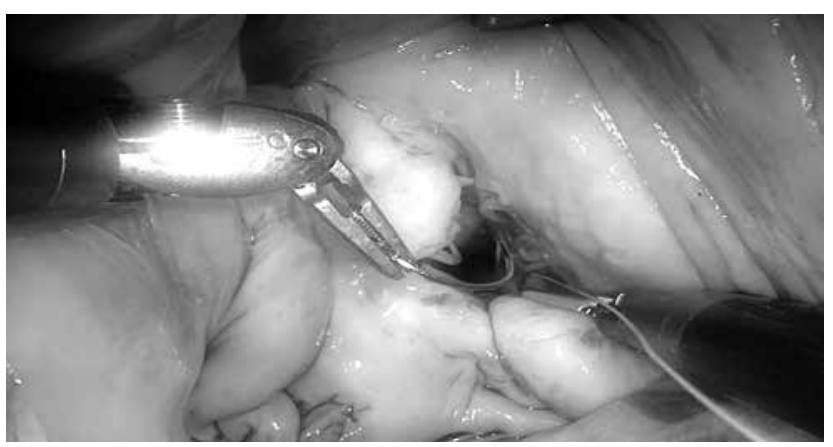

Figure 2. An endoscopic image showing magnified threedimensional image and dynamic atrial retractor providing excellent exposure to mitral valve and subannular anatomy. Technology allows intervention at more proximity to the surgical field. 
patient population were some of the other limitations of our report.

In conclusion, robotic-assisted concomitant procedures during mitral valve surgery can be performed with low complication rates in centers with the experience of robotic cardiac surgery. We believe that technological improvements and growing experience would further decrease the suspects related to prolonged operational duration during roboticassisted cardiac surgery.

\section{Declaration of conflicting interests}

The authors declared no conflicts of interest with respect to the authorship and/or publication of this article.

\section{Funding}

The authors received no financial support for the research and/or authorship of this article.

\section{REFERENCES}

1. Lewis CT, Stephens RL, Tyndal CM, Cline JL. Concomitant robotic mitral and tricuspid valve repair: technique and early experience. Ann Thorac Surg 2014;97:782-7.

2. Loulmet DF, Ranganath NK, Neuburger PJ, Nampiaparampil RG, Galloway AC, Grossi EA. Can complex mitral valve repair be performed with robotics? An institution's experience utilizing a dedicated team approach in 500 patients. Eur J Cardiothorac Surg 2019;56:470-8.

3. Murphy DA, Moss E, Binongo J, Miller JS, Macheers SK, Sarin EL, et al. The expanding role of endoscopic robotics in mitral valve surgery: 1,257 Consecutive procedures. Ann Thorac Surg 2015;100:1675-81.
4. Gillinov AM, Mihaljevic T, Javadikasgari H, Suri RM, Mick SL, Navia JL, et al. Early results of robotically assisted mitral valve surgery: Analysis of the first 1000 cases. J Thorac Cardiovasc Surg 2018;155:82-91.

5. Senay S, Gullu AU, Alhan C. Robotic mitral valve replacement for rheumatic mitral disease. Ann Cardiothorac Surg 2017;6:64-6.

6. Gullu AU, Senay S, Kocyigit M, Alhan C. A simple method for occlusion of both venae cavae in total cardiopulmonary bypass for robotic surgery. Interact Cardiovasc Thorac Surg 2012;14:138-9.

7. Efird JT, Griffin WF, Gudimella P, O'Neal WT, Davies SW, Crane $\mathrm{PB}$, et al. Conditional long-term survival following minimally invasive robotic mitral valve repair: a health services perspective. Ann Cardiothorac Surg 2015;4:433-42.

8. Arnaz A, Gullu AU, Akyol A, Zencirci E, Senay S, Alhan C. Application of cryoablation for the treatment of atrial fibrillation in patients undergoing cardiac surgery: Our midterm results. Turk Gogus Kalp Dama 2018;26:8-13.

9. Xiao C, Gao C, Yang M, Wang G, Wu Y, Wang J, et al. Totally robotic atrial septal defect closure: 7-year singleinstitution experience and follow-up. Interact Cardiovasc Thorac Surg 2014;19:933-7.

10. Onan B, Kadiroğulları E, Aydın Ü, Güner Y, Erkanlı K. Totally endoscopic robotic atrial septal defect closure in an adult with Down syndrome. Turk Gogus Kalp Dama 2017;25:450-4.

11. Bakir I, Onan B, Kadirogullari E. Robotically assisted repair of partial atrioventricular canal defect. Artif Organs 2016;40:917-8.

12. Nifong LW, Rodriguez E, Chitwood WR Jr. 540 consecutive robotic mitral valve repairs including concomitant atrial fibrillation cryoablation. Ann Thorac Surg 2012;94:38-42. 